\title{
An overview of available metamaterial-based antenna for non- invasive hyperthermia cancer treatment
}

\author{
Nabilah Abdul Jaffar', Norlida Buniyamin', Kasumawati Lias ${ }^{3}$ \\ ${ }^{1,2}$ Faculty of Electrical Engineering, Universiti Teknologi MARA (UiTM), Malaysia \\ ${ }^{3}$ Faculty of Engineering, Universiti Malaysia Sarawak (UniMAS), Malaysia
}

\section{Article Info \\ Article history: \\ Received Sep 23, 2018 \\ Revised Dec 25, 2018 \\ Accepted Jan 14, 2019}

\section{Keywords:}

Left-Handed metamaterial (LHM)

Non-Invasive hyperthermia Non-Invasive hyperthermia cancer treatment (NIHCT) Specific absorption rate (SAR)

\begin{abstract}
This paper presents the outcome of a literature review that an overview of various types of antenna and metamaterial applicator performance towards cancerous tissue or cell for non-invasive hyperthermia cancer treatment (NIHCT) procedure. From the review, it shows that when LHM lens integrated with an antenna, focusing capabilities of the antenna towards the cancerous area can be improved. However, current applicators have a poor focusing effect when directed towards the actual tumor area. In conjunction with that, this paper proposes a new design of modified applicator that is microstrip antenna integrated with left-handed metamaterial (LHM) lens. The antenna termed microstrip-LHM (M-LHM) lens antenna is proposed for use in NIHCT. It is expected to improve the focusing capabilities of an antenna which is used to kill the cancerous area and thus improve the hyperthermia cancer treatment procedure success rate. In addition, this paper provides an overview of heating techniques used in hyperthermia to enhance focusing capabilities and a few metamaterial advantages that can improve the focusing effect and reduced the hot-spots. Specific Absorption Rate (SAR) will be investigated to evaluate the focusing abilities of the proposed applicator using the SEMCAD X Solver.
\end{abstract}

Copyright $\odot 2019$ Institute of Advanced Engineering and Science. All rights reserved.

\section{Corresponding Author:}

Nabilah Abdul Jaffar,

Faculty of Electrical Engineering,

Universiti Teknologi MARA (UiTM),

40450 Shah Alam, Selangor, Malaysia,

Email: nabilah_ajmb@yahoo.com

\section{INTRODUCTION}

Non-Invasive hyperthermia cancer treatment procedure (NIHCT) is a popular technique that is now used to treat cancer patients. The NIHCT procedure can be used independently. However, it is commonly used as an adjuvant therapy to support various invasive treatment procedures such as chemotherapy and radiotherapy treatment. NIHCT, sometimes referred to as thermotherapy is a type of cancer treatment in which body tissue is exposed to a relatively high temperature. It is a treatment which requires high temperature around $41^{\circ} \mathrm{C}-45^{\circ} \mathrm{C}$ to kill the cancerous tissue by a denaturation process. NIHCT process induces cell death with minimal side effects [1], [2].

NIHCT artificially heats body tissue using electromagnetic (EM) waves by focusing the EM wave onto the cancerous cell area thus heating the selected cells to induce denaturation. One of the challenges in the hyperthermia treatment is to selectively heat an area where the cancerous tissues are located to elevate the cancerous cell temperature to above $42{ }^{\circ} \mathrm{C}$ while keeping the temperatures of the surrounding healthy tissue as close as possible to normal human body temperature [3], [4]. Thus, to provide a good NIHCT is to have an antenna or applicator of the EM waves that could provide a good focusing control parameter.

Hyperthermia cancer treatment can be delivered either invasive or non-invasive. According to [5], NIHCT is a promising technique which gives a safe and effective treatment with less hurt and injury to fight 
against various types of cancer. However, non-invasive hyperthermia performance during the treatment had the side effect especially skin burn and caused unwanted hot-spots which may affect the other surrounding healthy tissue. Due to this hyperthermia weakness, researchers developed a various design of antenna/applicator to minimize the sides effect of the treatment.

An antenna is an electromagnetic radiator that creates an Electromagnetic (EM) field that proceeds out from the transmitting antenna to the receiver's antenna, which then converts the electromagnetic wave into electrical signals that are applied to the receiver's input stages. It also acts as a radiator and heat generator for hyperthermia cancer treatment procedure. Currently, integration of metamaterial slab and lens to the antenna design has increased rapidly among the researchers, where it gives good performance in terms of focusing effect towards the cancerous area to be treated.

In conjunction with that, this paper proposes a new design of modified applicator that is microstrip antenna integrated with cylindrical left-handed metamaterial (LHM) lens. The proposed M-LHM lens is expected to improve focusing capabilities which can be used to kill cancerous tissues and reduce unwanted hot-spots that may cause damage to surrounding healthy tissues during NIHCT.

\section{M-LHM LENS ANTENNA: AN ENHANCED MICROSTRIP ANTENNA FOR NIHCT}

An antenna is the main part for hyperthermia applicator that will be used to kill/destroy the cancerous tissues or cells which will ensure the quality of hyperthermia treatment performance. The use of an appropriate antenna is very important as heat generated by the electromagnetic (EM) fields will be used for treatment to destroy or kill the cancerous cells [6]. Various types of antenna have been developed and investigated by previous researchers to obtain the quality of non-invasive hyperthermia cancer treatment. The evolution in antenna development for NIHCT procedure is depicted in Figure 1.

From observation in Figure 1, a microstrip antenna has shown the highest numbers of usage every year with 12 published papers from the year of 2013 until 2017 where the highest number is in 2014 with 4 published papers followed by 3 papers in 2015, 2 papers in 2016 and 2017 and 1 paper in 2013. Then, planar array antenna and waveguide antenna has been investigated 2 times in 2013 and 2014 and 1 time in 2015 and 2016 respectively. Meanwhile, yagi-uda antenna can be found in the year 2013 and 2017 with 1 and 1 published papers, respectively. On the other hand, coaxial antenna has been investigated 1 time in the year 2015 and 2016. The other types of antennas that have been presented for non-invasive hyperthermia cancer treatment application such as choke ring antenna and square ring antenna have been introduced in the year 2013 and 2017 with accordingly, 1 and one published paper. Figure 2 shows a few types of antennas which have been used in NIHCT investigation.

As shown in Figure 1, the evolution of various common types of antenna that have been designed for investigation are the square ring, microstrip, planar array, yagi-uda, coaxial, waveguide and choke ring antenna.

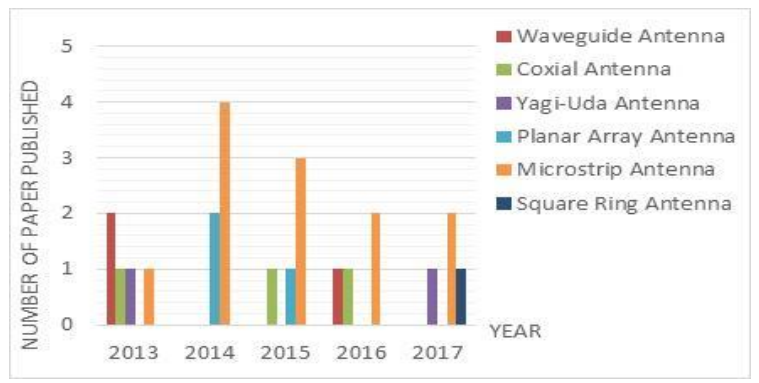

Figure 1. Evolution of various types of antennas used in Non-Invasive Hyperthermia Cancer Treatment (NIHCT) procedure

Various shapes, sizes, and structures of antennas to have been designed to improve and enhance the performance of NIHCT is shown in Figure 2. It shows that microstrip antenna gives the good results towards NIHCT. In addition, the microstrip antenna is chosen in this research because it gives high performance in NIHCT due to its light in weight, flexible and small in size which can be enhanced to various array types and flexible with multi-frequency operation [6], [15]. It is also good for miniaturization factor, and it provides narrowband radiation pattern which can give consistently in focusing towards cancerous tissue [16]. All this characteristic of microstrip made it suitable for this NIHCT investigation. 


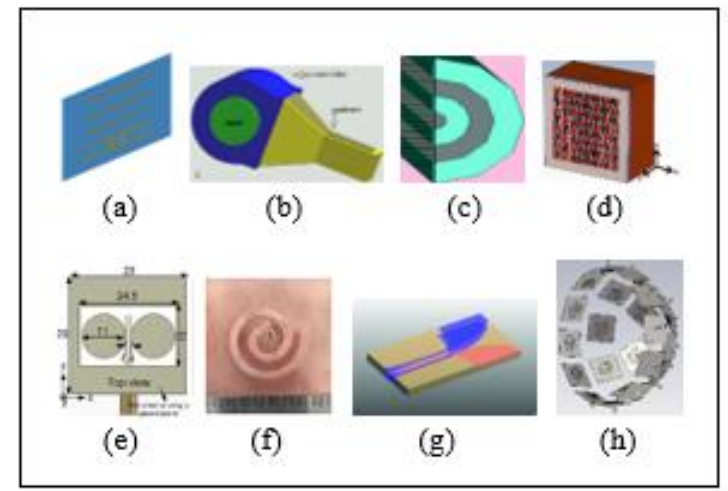

Figure 2. Examples of antennas that have been used for NIHCT, (a) yagi-uda antenna [7] (b) waveguide horn antenna [8],(c) coaxial-slot antenna [9] (d) planar array antenna [10] (e) microstrip slot antenna [11] (f) planar microstrip spiral antenna [12] (g) Vivaldi antenna [13] (h) microstrip spiral hemispherical array antenna [14]

However, few limitations have been observed where the current existing applicators had poor focusing capabilities towards the actual tumor area to be treated. Hence, the surrounding healthy cells are affected, and the side effect of skin burn happens. From the observation obtained from the previous researchers, applicators can produce deep heating. However, the over-heating and wider focusing on the treated cancerous tissue are produced.

Therefore, this current research will introduce the LHM lens which will be integrated with a modified rectangular microstrip antenna as to investigate the impact on the focusing capabilities towards the cancerous area and to reduce the unwanted hot-spot for non-invasive hyperthermia cancer treatment. There are other methods used by previous researchers to enhance the focusing capabilities towards the cancerous area as discussed in the next section.

\section{HEATING TECHNIQUES USED TO ENHANCE FOCUSING CAPABILITIES IN NON- INVASIVE MICROWAVE HYPERTHERMIA}

Various techniques for non-invasive hyperthermia treatment are examined by previous studies to induce heating of the targeted cancerous area without affecting the surrounding healthy tissues. The techniques that had been used are Ultrasound thermal therapy, microwave electromagnetics, and computational techniques as illustrated in Table 1.

Table 1. Heating Techniques Used in Hyperthermia

\begin{tabular}{|c|c|c|}
\hline $\begin{array}{l}\text { Heating Techniques } \\
\text { used in Hyperthermia }\end{array}$ & Advantages & Disadvantages \\
\hline $\begin{array}{l}\text { Ultrasound Thermal } \\
\text { Therapy } \\
{[17],[18],[19]}\end{array}$ & $\begin{array}{l}\text { Good Focusing effect and deep } \\
\text { penetration. }\end{array}$ & $\begin{array}{l}\text { Reflected energy does not refocus } \\
\text { within the soft tissue and high absorption in the bone that } \\
\text { cause heating of the bone. }\end{array}$ \\
\hline $\begin{array}{l}\text { Microwave } \\
\text { Electromagnetics } \\
{[20],[21],[22],[23]}\end{array}$ & $\begin{array}{l}\text { EM energy is not blocked by bones, } \\
\text { can be performed by single or } \\
\text { multiple applicators and phase array } \\
\text { antenna and multiple applicators } \\
\text { can be used for larger tumor volume. }\end{array}$ & Over-heating and skin burns occur. \\
\hline $\begin{array}{l}\text { Computational } \\
\text { Techniques }(2 \mathrm{D} \text { and } 3 \mathrm{D} \\
\text { Time-reversal based) } \\
{[24],[16],[25],[26]}\end{array}$ & $\begin{array}{l}\text { Gives good focusing and provide } \\
\text { necessary temperature gradient for } \\
\text { microwave hyperthermia. }\end{array}$ & $\begin{array}{l}\text { Not so practical because of the usage of oversimplified } \\
\text { propagation models. }\end{array}$ \\
\hline
\end{tabular}

From Table 1, the microwave electromagnetics heating technique could provide a better effective treatment to fight against various types of cancer with less hurt and injury. However, it can cause overheating and skin burns which can affect the other surrounding healthy tissue. Due to this weakness, a various design of applicator is conducted by previous researchers to minimise the side effect occurs. 
Therefore, this paper is focused on enhancing the hyperthermia cancer treatment procedure using microwave electromagnetics as a heating technique which can give heat that needed for the treatment procedure performance. Furthermore, microwave electromagnetics can be performed by single or multiple applicators and can be further enhancing and modifying the applicator to get the better focusing effect. Various types of antenna/applicator are being discussed in the previous section. Metamaterial applicator is proposed in this research, where its characteristics are discussed in [27], and its advantages are elaborated in the next section.

\section{METAMATERIALS ADVANTAGES}

A metamaterial is artificially materials which have the electromagnetic properties that may not found in nature. Since the metamaterial unusual properties, it has led to the development of metamaterial antennas, sensors and metamaterial lenses for miniature wireless systems and for biomedical application which are more efficient than their conventional materials. The gain profile, efficiency, and bandwidth requirements were enhanced by the usage of metamaterials in various antenna designing and fabrication. The advantages of metamaterial are:

\subsection{Improvement of Directivity}

Metamaterials have the inherent property that controls the direction of electromagnetic radiation to collect the originating energy in a small angular domain around the normal to the surface [28]. A Double Negative (DNG) material which known as LHM lens enhances the directive properties of an antenna.

\subsection{Enhancement of Bandwidth}

Bandwidth performance increases by the use of metamaterials antenna as compared to the conventional patch antenna [29]. This is achieved by use of superstrate of metamaterial over the conventional antenna or by loading of LHM.

\subsection{The Reduction of Beam Width and Side Lobes}

The metamaterials antennas decrease the beam width and side lobe ratio [30] and thus enhance the directivity and reduce the return loss of the antenna. All the above metamaterial advantages prove that it will give good performance towards NIHCT, where the directivity of the antenna, good bandwidth, and decrement of beam width and side lobe can give better specific absorption rate (SAR) in term of focusing effect and heating towards the cancerous area to be treated. Currently, research in the development of an integration of metamaterial in an antenna design for hyperthermia cancer treatment has grown rapidly as discussed in the next section.

\section{METAMATERIALS IN MICROWAVE HYPERTHERMIA}

Microwaves are used to destroy or ablate diseased soft-tissue by heating the tissue to a temperature that causes cell death is called hyperthermia. The generator produces microwave energy which is transmitted through the antennas and into the patient. Elevating the temperature of tumor cells causes cell membrane damage, which leads to the destruction of the cancer cells. Hyperthermia treatment of cancer requires directing a carefully controlled dose of heat to the cancerous tumor and surrounding body tissue. The most prominent property of metamaterial lens is the ability of negative-refractive index (NRI) to focus the electromagnetic field of a source [31]. Hence it can generate appropriate focusing spot in biological tissue as required in microwave hyperthermia treatment shown in Figure 3. Flat metamaterial slab has been used as a lens to focus microwave energy emitted from the microwave source.

Further, the convenient adjustment of the position of focusing or heating spot in tissue region gives the great potential to successful microwave hyperthermia [32]. By moving the source, the heating spot in tissue can be adjusted, without any complex deployment and control system as required in the conventional array applicator [33]. Recently, conformal microwave array applicators proposed with proper source spacing, low loss left-handed metamaterial lens can be useful for hyperthermia treatment of large area tumors. In this, microwave hyperthermia can be performed by joint heating of multiple microwave sources [32].

The evaluation of the focusing performance of LHM system as shown in Figure 3. In the focusing,

the source lens distance $d_{1}$, the lens thickness, $d$ and the focal length, $d_{2}$ theoretically obey the following relation:

$$
d=d_{1}+d_{2}
$$


Which implies the focal point of a flat LHM lens can be adjusted in the breast by moving the source, and thus the thickness of LHM lens is determined by the required detection depth in the breast. Metamaterial technology was further developed to lenses, where LHM slab can act as a lens that will focus the incident waves. The most prominent property of LHM lens is the ability of negative-refractive index (NRI) to focus the electromagnetic field of a source. Hence it can generate appropriate focusing spot in biological tissue as required in microwave hyperthermia treatment.

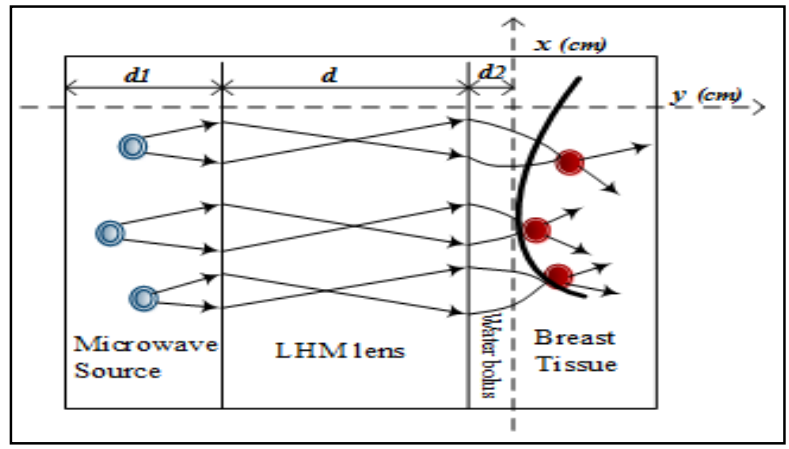

Figure 3. Focusing scheme by using LHM Lens

As shown in Table 2, most of the researchers used practical, biconical dipole, half-wave and waveguide antenna with the integration of LHM lens but no researchers had used microstrip antenna as a microwave source. In conjunction with that, this paper introduces microstrip antenna integrated with LHM lens that can give better focusing capabilities towards the cancerous tissue to be treated. Furthermore, it can be concluded that to provides heating zone better fit the tumor and good focusing capabilities towards the tumor area, the following methods have been introduced by previous researchers that can be applied:

a) Joint heating of multiple sources,

b) Adjust the source-to-lens distance,

c) Adjust the applicator distance towards the cancerous area,

d) Adjust the phases of microwave sources to adjust the inclination of the heating zone,

e) Varying the thickness of the lens.

The method above gives a promising effect towards hyperthermia treatment to selectively heat the cancerous tissue, elevating its temperature above $42{ }^{\circ} \mathrm{C}$, while keeping the temperatures of the healthy tissue close to the normal temperature of the human body. Figure 4 and 5 shows the historical timeline of metamaterial slab and lens from 2007 until 2016.

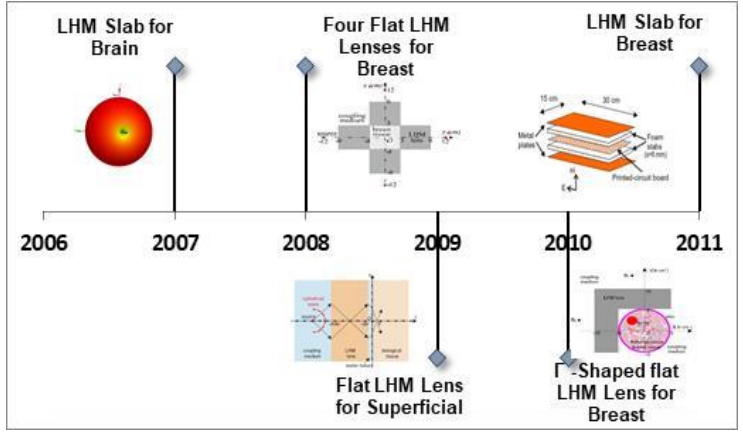

Figure 4. Historical timelines of metamaterial slab and lens from 2007 until 2011

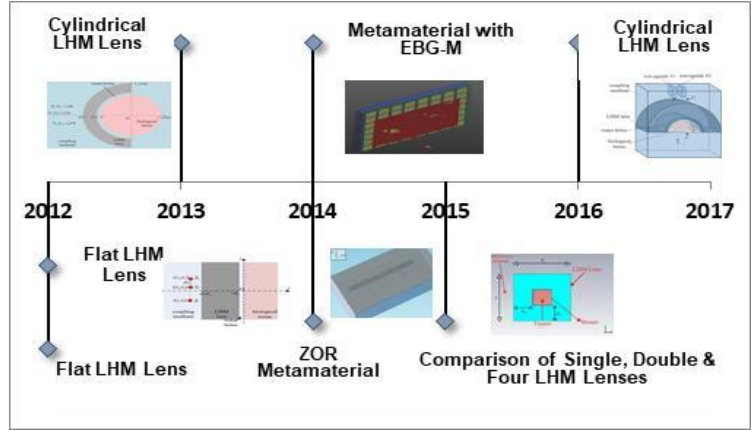

Figure 5. Historical timeline of metamaterial slab and lens from 2012 until 2016

Various shapes and design of metamaterial slab and lens had designed by previous researchers as shown in Figure 4 and 5. The purpose is to increase the focusing effect towards the cancerous cell and to minimize the unwanted hot-spots and skin burns. 
Table 2. Shows a Summary of Recent Research of Left-Handed Metamaterial (LHM) Slab and Lens

\begin{tabular}{|c|c|c|c|c|}
\hline Year and Author & $\begin{array}{c}\text { Microwave } \\
\text { Hyperthermia } \\
\text { Applicator }\end{array}$ & $\begin{array}{c}\text { Types of } \\
\text { Antenna Used }\end{array}$ & $\begin{array}{c}\text { Types of } \\
\text { Cancerous } \\
\text { Tissues } \\
\end{array}$ & Observation \\
\hline $\begin{array}{l}\text { Konstantinos } \\
\text { T.K., Irene S.K, } \\
\text { et al. } 2007 \text { [34] }\end{array}$ & $\begin{array}{c}\text { Single Flat LHM } \\
\text { lens }\end{array}$ & $\begin{array}{l}\text { Biconical } \\
\text { dipole } \\
\text { antenna }\end{array}$ & Deep Brain & $\begin{array}{l}\text { Integration of LHM lens improves the system's focusing } \\
\text { properties and penetration depth of EM Wave and } \\
\text { magnitude of the field inside the head model. }\end{array}$ \\
\hline $\begin{array}{l}\text { Yu Gong, } \\
\text { Hongjin Wang, } \\
\text { Gang Wang, } \\
2008[35]\end{array}$ & $\begin{array}{l}\text { Four Flat Left- } \\
\text { Handed } \\
\text { Metamaterial } \\
\text { (LHM) Lenses }\end{array}$ & $\begin{array}{l}\text { Practical } \\
\text { Antenna }\end{array}$ & $\begin{array}{l}\text { Breast } \\
\text { Tissue }\end{array}$ & $\begin{array}{l}\text { Four-LHM slab lens gives better focusing and } \\
\text { penetration depth by varying the thickness of the lens } \\
\text { and adjusting the source position. }\end{array}$ \\
\hline $\begin{array}{l}\text { Y.Gong and } \\
\text { G.Wang, } 2009 \\
{[33]}\end{array}$ & $\begin{array}{l}\text { Single Flat Left- } \\
\text { Handed } \\
\text { Metamaterial Lens }\end{array}$ & $\begin{array}{l}\text { Practical } \\
\text { Antenna }\end{array}$ & $\begin{array}{l}\text { Superficial } \\
\text { Tumor }\end{array}$ & $\begin{array}{l}\text { The result of the temperature distribution indicates that } \\
\text { flat LHM lens is suitable for superficial hyperthermia } \\
\text { applicator. LHM lens permittivity and permeability at } \\
\text { the } 915 \mathrm{MHz} \text { operation frequency give a good } \\
\text { performance. }\end{array}$ \\
\hline $\begin{array}{l}\text { Yonghui Tao and } \\
\text { Gang Wang, } \\
2010[36]\end{array}$ & $\begin{array}{l}\Gamma \text {-Shaped flat } \\
\text { LHM Lens } \\
\text { Applicator }\end{array}$ & $\begin{array}{l}\text { Practical } \\
\text { Antenna }\end{array}$ & Breast Tissue & $\begin{array}{l}\text { The highest temperature measured in the tumor can } \\
\text { reach } 43^{\circ} \mathrm{C} \text { only when the two sources behind the LHM } \\
\text { lens applicator are correctly deployed to coincide in the } \\
\text { tumor area. }\end{array}$ \\
\hline $\begin{array}{l}\text { Maria C.V, } \\
\text { Manuel J.F, et.al, } \\
2011[37]\end{array}$ & LHM Slab & $\begin{array}{l}\text { Planar array } \\
\text { split-rings } \\
\text { antenna }\end{array}$ & Breast Tissue & $\begin{array}{l}\text { The hyperthermia experimented with a square breast } \\
\text { phantom and a spherical tumor deep inside it. The } \\
\text { focusing effects towards the breast tumor is an } \\
\text { acceptable level. }\end{array}$ \\
\hline $\begin{array}{l}\text { Yonghui Tao and } \\
\text { Gang Wang, } \\
2012[32]\end{array}$ & Flat LHM lens & $\begin{array}{l}\text { Practical } \\
\text { Antenna }\end{array}$ & $\begin{array}{l}\text { Large } \\
\text { Superficial } \\
\text { Tumor }\end{array}$ & $\begin{array}{l}\text { Multiple sources behind a flat LHM slab lens is } \\
\text { proposed which it indicates that it was feasible to } \\
\text { acquire larger heat zone. The focusing capability on the } \\
\text { tumor region was given less attention. }\end{array}$ \\
\hline $\begin{array}{l}\text { Yonghui Tao and } \\
\text { Gang Wang, } \\
2012[38]\end{array}$ & Flat LHM lens & $\begin{array}{l}\text { Waveguide } \\
\text { Antenna }\end{array}$ & $\begin{array}{l}\text { Conformal } \\
\text { Hyperthermia } \\
\text { Superficial } \\
\text { Tumor }\end{array}$ & $\begin{array}{l}\text { It is acquired by joint heating of multiple sources to } \\
\text { shape the heating zone to get better heating zone that fit } \\
\text { large superficial tumor and the inclination of the heating } \\
\text { zone is adjusted by properly set the source-to-lens } \\
\text { distance of sources. The results give moderate focusing } \\
\text { spot towards tumor area. }\end{array}$ \\
\hline $\begin{array}{l}\text { Yonghui Tao and } \\
\text { Gang Wang, } \\
2013[39]\end{array}$ & $\begin{array}{l}\text { Cylindrical LHM } \\
\text { lens }\end{array}$ & $\begin{array}{l}\text { Practical } \\
\text { Antenna }\end{array}$ & $\begin{array}{l}\text { Superficial } \\
\text { Tumor }\end{array}$ & $\begin{array}{l}\text { By using multiple sources and adjusting source distance } \\
\text { properly, the tumor with large sizes are completely } \\
\text { heated and focusing position adjusted by change the } \\
\text { thickness of the lens. }\end{array}$ \\
\hline $\begin{array}{l}\text { Luca Leggio, } \\
\text { Omar de Varona } \\
\text { and Ehsan } \\
\text { Dadrasnia, } 2015 \\
\text { [40] }\end{array}$ & $\begin{array}{l}\text { Single-LHM } \\
\text { Lens, Double- } \\
\text { LHM Lens, and } \\
\text { Conformal Four- } \\
\text { LHM Lenses }\end{array}$ & $\begin{array}{l}\text { Half-Wave } \\
\text { Antenna }\end{array}$ & Breast Tissue & $\begin{array}{l}\text { Four LHM lenses provide better focusing rather than } \\
\text { single and double LHM lens. The heating area is } \\
\text { adjusted by moving the antennas or by varying the } \\
\text { thickness of the LHM lenses based on the tumor } \\
\text { position. }\end{array}$ \\
\hline $\begin{array}{l}\text { Yonghui Tao and } \\
\text { Gang Wang, } \\
2016[38]\end{array}$ & $\begin{array}{l}\text { Cylindrical LHM } \\
\text { lens }\end{array}$ & $\begin{array}{l}\text { Waveguide } \\
\text { Antenna }\end{array}$ & $\begin{array}{l}\text { Large } \\
\text { Superficial } \\
\text { Tumor }\end{array}$ & $\begin{array}{l}\text { Joint heating of multiple sources ( } 2 \text { rectangular } \\
\text { waveguide antenna), adjusting the source-to-lens } \\
\text { distance and phases of microwave sources give heating } \\
\text { zone better fit the tumor. }\end{array}$ \\
\hline
\end{tabular}

In 2008, Yu Gong [35] had introduced LHM lens in hyperthermia cancer treatment technology. Four flat LHM lenses applicator are deployed for breast tumor hyperthermia. When tumor position is adjusted to some extent, the results indicate that the focusing effect is less affected.

One flat LHM lens has been investigated in [33] for superficial tumor, where only one source is set behind a flat LHM lens. The heating zone in tissue can also be easily adjusted in both lateral and depth direction in tissue as required in hyperthermia when the microwave source position is adjusted.

Furthermore, the feasibility of multiple sources sharing one flat lens has been introduced by Yonghui Toa in [32] for large superficial tumor and conformal hyperthermia of superficial tumor was investigated in [38]. The results indicate a relatively large heating zone for hyperthermia cancer treatment.

Single, double and conformal four- LHM lenses have been compared in [40]. It indicates that multilens systems had shown the better alternative to produce temperature concentration within the tumors compared to single-lens. Superficial hyperthermia with a cylindrical LHM lens [39] and Cylindrical LHM lens for conformal hyperthermia of superficial tumors is introduced in [41]. Both demonstrated better focusing effect results towards the cancerous region to be treated compared to other shapes of lenses. Furthermore, it indicates that, by using multiple microwave sources and properly setting the source-to-lens distance or phases, a better heating zone that gives that fit to the large superficial tumors could be produced.

Based on the reviews, current existing applicator could not focus very well on the targeted cancerous region Therefore, microstrip antenna integrating with cylindrical LHM lens applicator will be 
designed guided by combining results from various researchers that have developed LHM lens applicator for hyperthermia. In conjunction with that, a new modified microstrip antenna integrated with LHM lens will be proposed to enhance the existing applicator which can give better focusing capabilities. From the observation, its shows that cylindrical LHM lens gives better focusing capabilities rather than other shape of LHM lens.

\section{CONCLUSION}

An overview of various types of antenna and metamaterial applicators performance towards NIHCT was presented. Many researchers in Electromagnetic fields based on hyperthermia treatment are focus on antenna design. While less work has been done in focusing techniques during hyperthermia treatment. From the review done, Left-handed metamaterial (LHM) lens when integrated with an antenna can enhance the focusing capabilities of the antenna to treat the cancerous area. However, the current applicator had poor focusing capabilities towards the actual tumor area. Thus, a new design of modified applicator that is microstrip antenna integrated with left-handed metamaterial (LHM) lens is proposed. It is expected to improve hyperthermia treatment performance mainly in term of focusing capabilities to kill cancerous tissues and minimise the side effect to the surrounding healthy tissues during the hyperthermia cancer treatment procedure.

\section{ACKNOWLEDGEMENT}

The authors would like to acknowledge and thank Universiti Teknologi MARA (UiTM) for the "Grant Inisiatif Penyeliaan" (600-IRMI/GIP 5/3(075/2017).

\section{REFERENCES}

[1] J. Vrba, "Microstrip Applicator for Local Hyperthermia," pp. 1047-1049, 2007.

[2] O. Losito, M. Bozzetti, S. Sterlacci, and V. Dimiccoli, "E-field distribution improvement by new hyperthermia applicators," MeMeA 2011 - 2011 IEEE Int. Symp. Med. Meas. Appl. Proc., pp. 1-5, 2011.

[3] A. A. S. Amad, A. F. D. Loula, and A. A. Novotny, "A new method for topology design of electromagnetic antennas in hyperthermia therapy," Appl. Math. Model., vol. 42, pp. 209-222, 2017.

[4] G. Hegyi, G. P. Szigeti, and A. Szász, "Hyperthermia versus oncothermia: Cellular effects in complementary cancer therapy," Evidence-based Complement. Altern. Med., vol. 2013, 2013.

[5] K. B. Lias, M. Zulkarnaen, A. Narihan, and N. Buniyamin, "An Antenna with an Embedded EBG Structure for Non Invasive Hyperthermia Cancer Treatment An Antenna with an Embedded EBG Structure for Non Invasive Hyperthermia Cancer Treatment," 2015, no. December 2014.

[6] K. Bt Lias, N. Buniyamin, and M. Z. B. Ahmad Narihan, "An overview of cancer thermal therapy technology based on different types of antenna exposure," in 2013 International Conference on Electrical, Electronics and System Engineering, ICEESE 2013, 2013, pp. 96-101.

[7] M. M. Paulides, R. M. C. Mestrom, G. Salim, B. B. Adela, W. C. M. Numan, T. Drizdal, D. T. B. Yeo, and A. B. Smolders, "A printed Yagi-Uda antenna for application in magnetic resonance thermometry guided microwave hyperthermia applicators," Phys. Med. Biol., vol. 62, no. 5, pp. 1831-1847, 2017.

[8] J. Vrba and B. Vrbova, "Microwave Thermotherapy: Study of Hot-Spots Induced by Electromagnetic Surface Waves," no. Eucap, pp. 3125-3126, 2013.

[9] O. B. Debnath, K. Ito, K. Saito, and M. Uesaka, "Design of invasive and non-invasive antennas for the combination of microwave-hyperthermia with radiation therapy," pp. 1-2.

[10] K. J. Kim, W. C. Choi, Y. J. Yoon, and S. H. Bae, "Planar array for non-invasive ultra-superficial hyperthermia applicator," 2015 Int. Work. Antenna Technol. iWAT 2015, pp. 104-106, 2015.

[11] S. Singh and S. P. Singh, "Microstrip slot antenna for hyperthermia applications," 2015 IEEE Appl. Electromagn. Conf. AEMC 2015, vol. 2, pp. 15-16, 2016.

[12] E. Korkmaz, O. Isik, and M. A. Nassor, "A compact microstrip spiral antenna embedded in water bolus for hyperthermia applications," Int. J. Antennas Propag., vol. 2013, 2013.

[13] I. Merunka, O. Fiser, L. Vojackova, J. Vrba, and D. Vrba, "Utilization potential of balanced antipodal Vivaldi antenna for microwave hyperthermia treatment of breast cancer," 8th Eur. Conf. Antennas Propagation, EuCAP 2014, vol. 6, no. EuCAP, pp. 706-710, 2014.

[14] E. Korkmaz, O. Is, and H. Sagkol, "A Directive Antenna Array Applicator for Focused Electromagnetic Hyperthermia Treatment of Breast Cancer," vol. 1.

[15] R. Garg, Microstrip antenna design handbook. 2001.

[16] M. Converse, E. J. Bond, B. D. Van Veen, and S. C. Hagness, "A computational study of ultra-wideband versus narrowband microwave hyperthermia for breast cancer treatment," IEEE Trans. Microw. Theory Tech., vol. 54, no. 5, pp. 2169-2180, 2006.

[17] C. Ho, K. Ju, Y. Chen, and W. Lin, "Investigation of a Cylindrical Ultrasound Phased-Array with Multiple-Focus Scanning for Breast Tumor Thermal Therapy," pp. 6376-6379, 2006. 
[18] N. Y. City, "Heating Efficiency Improvement by Using A Spherically-Concaved Sectored Array in Focused Ultrasound Thermal Therapy," pp. 3807-3810, 2006.

[19] M. Shriwastava and V. R. Singh, "Tumour ablation with focussed ultrasound," IEEE/ Eng. Med. Biol. Soc. Annu. Conf., vol. 1, no. 5, pp. 3-4, 1995.

[20] “Isik,Korkmaz,IEEE AP-S," no. 1, pp. 2-5, 2010.

[21] D. Informatica, "Focused Microwave Thermotherapy : a Patient- Specific Numerical Assessment of a Non-Invasive Breast Cancer Treatment," pp. 3646-3650, 2011.

[22] W. Long, "Microstrip Near-Field Focusing for Microwave Non-invasive Breast Cancer Thermotherapy 2. Noninvasive Microwave Thermotherapy System 3. Focusing Enhancement in Microstrip Thermotherapy System," pp. 1-4, 2014.

[23] P. T. Nguyen, A. Abbosh, and S. Crozier, "Microwave hyperthermia for breast cancer treatment using electromagnetic and thermal focusing tested on realistic breast models and antenna arrays," IEEE Trans. Antennas Propag., vol. 63, no. 10, pp. 4426-4434, 2015.

[24] P. T. Nguyen and A. M. Abbosh, "Focusing Techniques in Breast Cancer Treatment Using Non-invasive Microwave Hyperthermia," pp. 2-4, 2015.

[25] P. Kosmas and C. M. Rappaport, "FDTD-based time reversal for microwave breast cancer Detection-localization in three dimensions," Microw. Theory Tech. IEEE Trans., vol. 54, no. 4, pp. 1921-1927, 2006.

[26] B. Guo, L. Xu, and J. Li, "Time reversal based microwave hyperthermia treatment of breast cancer," Microw. Opt. Technol. Lett., vol. 47, no. 4, pp. 335-338, 2005.

[27] N. A. Jaffar, K. B. Lias, N. K. Madzhi, and N. Buniyamin, "An Overview of Metamaterials Used in Applicators in Hyperthermia Cancer Treatment Procedure,” pp. 32-36, 2017.

[28] H. Zhou, Z. Pei, S. Qu, S. Zhang, J. Wang, Z. Duan, H. Ma, and Z. Xu, "A novel high-directivity microstrip patch antenna based on zero-index metamaterial," IEEE Antennas Wirel. Propag. Lett., vol. 8, pp. 538-541, 2009.

[29] J. H. Lu, "Bandwidth enhancement design of single-layer slotted circular microstrip antennas," IEEE Trans. Antennas Propag., vol. 51, no. 5, pp. 1126-1129, 2003.

[30] S. Enoch, G. Tayeb, P. Sabouroux, N. Guérin, and P. Vincent, “A Metamaterial for Directive Emission," Phys. Rev. Lett., vol. 89, no. 21, p. 213902, 2002.

[31] J. Hua, S. Huang, C. Yang, and Q. Wu, "High gain patch antenna with broadband metamaterial lens," Proc. 2012 5th Glob. Symp. Millimeter-Waves, GSMM 2012, no. Gsmm, pp. 79-82, 2012.

[32] Y. Tao and G. Wang, "Hyperthermia of large superficial tumor with a flat LHM lens," in IEEE MTT-S International Microwave Symposium Digest, 2012.

[33] J. Zhang, Y. Yin, and J. Ma, "Progress In Electromagnetics Research, PIER 96, 287-298, 2009," Superf. Tumor Hyperth. With Flat Left-Handed Metamaterial Lens, vol. 96, pp. 287-298, 2009.

[34] C. Internationale, K. T. Karathanasis, I. S. Karanasiou, and N. K. Uzunoglu, "Enhancing the Focusing Properties of a Prototype Non-Invasive Brain Hyperthermia System: a Simulation Study," pp. 218-221, 2007.

[35] G. Yu, W. Hongjin, and W. Gang, "Microwave heating by using flat LHM lens," META08 - Proc. 2008 Int. Work. Metamaterials, pp. 370-373, 2008.

[36] Y. Tao and G. Wang, "Influence of source offset on breast tumor hyperthermia with ??-shaped LHM lens applicator,” 2010 Int. Conf. Microw. Millim. Wave Technol. ICMMT 2010, pp. 1859-1861, 2010.

[37] M. C. Velazquez-Ahumada, M. J. Freire, and R. Marques, "Metamaterial applicator for microwave hyperthermia," 2011 30th URSI Gen. Assem. Sci. Symp. URSIGASS 2011, pp. 1-4, 2011.

[38] Y. Tao and G. Wang, "Conformal hyperthermia of superficial tumor with left-handed metamaterial lens applicator,” IEEE Trans. Biomed. Eng., vol. 59, no. 12, pp. 3525-3530, 2012.

[39] Y. Tao and G. Wang, "A New Hyperthermia Scheme with a Cylindrical LHM Lens," APCBEE Procedia, vol. 7, pp. 32-36, 2013.

[40] L. Leggio, O. De Varona, and E. Dadrasnia, "A Comparison between Different Schemes of Microwave Cancer Hyperthermia Treatment by Means of Left-Handed Metamaterial Lenses," Prog. Electromagn. Res., vol. 150, no. October 2014, pp. 73-87, 2015.

[41] D. Yin, M. Li, and J. L. Li, "Non-invasive Breast Cancer Thermotherapy Studies Using Conformal Microstrip Antennas," pp. 159-162.

\section{BIOGRAPHIES OF AUTHORS}

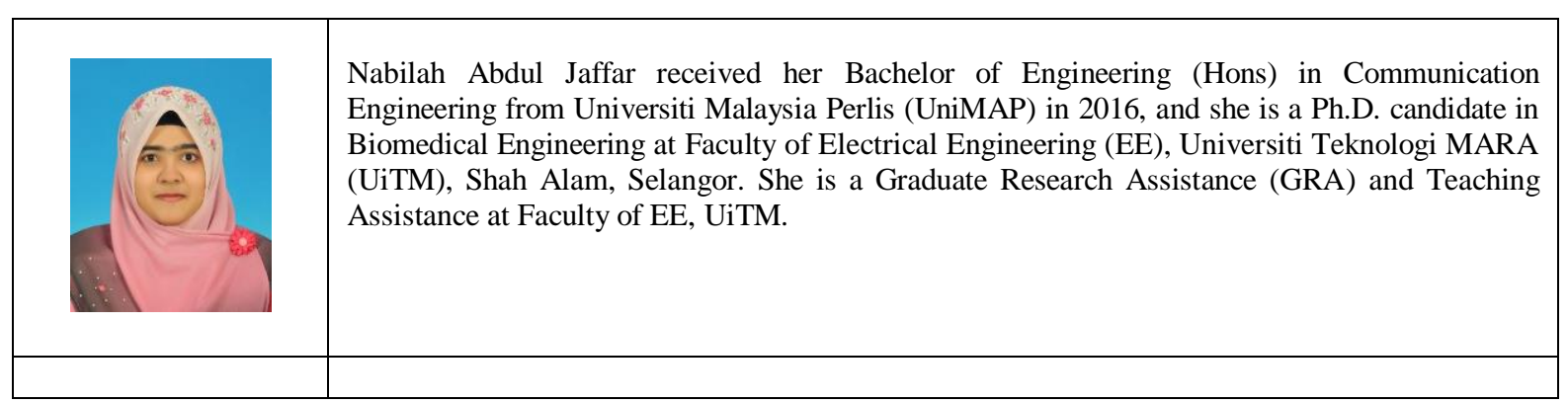

Indonesian J Elec Eng \& Comp Sci, Vol. 14, No. 2, May 2019 : 697 - 705 


Professor Ir. Dr Norlida Buniyamin graduated from the University of Adelaide, Australia with a
bachelor's degree in electrical and Electronic Engineering (Hons.). She was a Research Fellow
with the Malaysian Institute of Microelectronic Systems (MIMOS) before joining University
Teknologi MARA as a lecturer in 1988. She then obtained a M.Sc. in Industrial Control System
from the University of Salford, U.K in 1993 and a Ph.D. in the area of Knowledge Management
for Manufacturing Enterprises in 2004 from the University of Manchester, Institute of Science
and Technology (UMIST), U.K. She is now a Professor at UiTM, a Fellow of the Institution of
Engineers, Malaysia and Hon Fellow of the ASEAN Federation of Engineering Organisation
(AFEO). Her current research interest is in Industrial Automation and Robotics, Biomedical
Engineering, Knowledge Management and Engineering Education.

